\title{
Task 8.9 - Advanced Ceramic Materials
}

\author{
Topical Report \\ June 30, 1997
}

Work Performed Under Contract No.: DE-AC21-93MC30246

For

U.S. Department of Energy

Office of Fossil Energy

Federal Energy Technology Center

Morgantown Site

P.O. Box 880

Morgantown, West Virginia 26507-0880

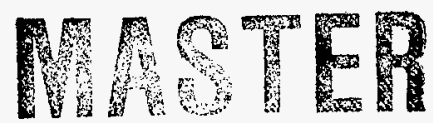

DhTAIEUTION OF THS DOCUMBNT is UNTHTED

Solar Turbines, Inc.

2200 Pacific Highway

San Diego, California 92186-5376 


\section{Disclaimer}

This report was prepared as an account of work sponsored by an agency of the United States Government. Neither the United States Government nor any agency thereof, nor any of their employees, makes any warranty, express or implied, or assumes any legal liability or responsibility for the accuracy, completeness, or usefulness of any information, apparatus, product, or process disclosed, or represents that its use would not infringe privately owned rights. Reference herein to any specific commercial product, process, or service by trade name, trademark, manufacturer, or otherwise does not necessarily constitute or imply its endorsement, recommendation, or favoring by the United States Government or any agency thereof. The views and opinions of authors expressed herein do not necessarily state or reflect those of the United States Government or any agency thereof. 


\section{CONTENTS}

Paragraph

Page

1.0

INTRODUCTION

1

2.0

SELECTION OF COMPONENTS AND PROGRAM GOALS

2

3.0

DESIGN, ANALYSIS AND FABRICATION OF THE TRANSITION DUCT

FIGURES

Figure

Page

1

Combustor to Nozzle Transition Duct for Can Annular Configuration

2

Preliminary Transition Duct Attachment Design

4

3

Stress Analysis Results for BFG Transition Duct

5 


\subsection{INTRODUCTION}

Advanced ceramic materials such as Continuous Fiber Reinforced Ceramic Matrix Composites (CFCCs) have had promising results on the companion program entitled "Ceramic Stationary Gas Turbine" (CSGT). In particular, CFCCs have outperformed monolithic tiles in structural integrity as a combustor liner. Also, CFCCs have provided the higher temperature operation and improved emissions performance that is required for the ATS combustor. The demonstrated advantages on CSGT justified work to explore the use of advanced ceramic composite materials in other gas turbine components. Sub-tasks include development of a practical, cost effective component fabrication process, development of finite element stress analysis to assure 30,000 hours of component life, and fabrication of a demonstration article.

The majority of the task was subcontracted to B.F. Goodrich Aerospace. Materials considered for the demonstration included carbon reinforced silicon carbide $(\mathrm{C} / \mathrm{SiC})$ and silicon carbide reinforced silicon carbide ( $\mathrm{SiC} / \mathrm{SiC}$ ). 


\subsection{SELECTION OF COMPONENTS AND PROGRAM GOALS}

Initially, components considered for development included a turbine interstage duct and a power turbine blade. Applicability of CFCCs in these components was more significant in an ICR gas turbine than in the optimized recuperated power plant. The component selected was the transition duct between the combustor liner and the stage one turbine annulus in the recuperated gas turbine (Figure 1).

The goals for this program are to:

- Demonstrate fabrication and tooling options for a transition duct.

- Validate properties for material system used in duct.

A two-dimensional braided construction was chosen for the fiber architecture. Panels fabricated from the same fiber architecture will be used for life prediction test coupons. A reusable graphite tooling approach will be used to fabricate the duct. 


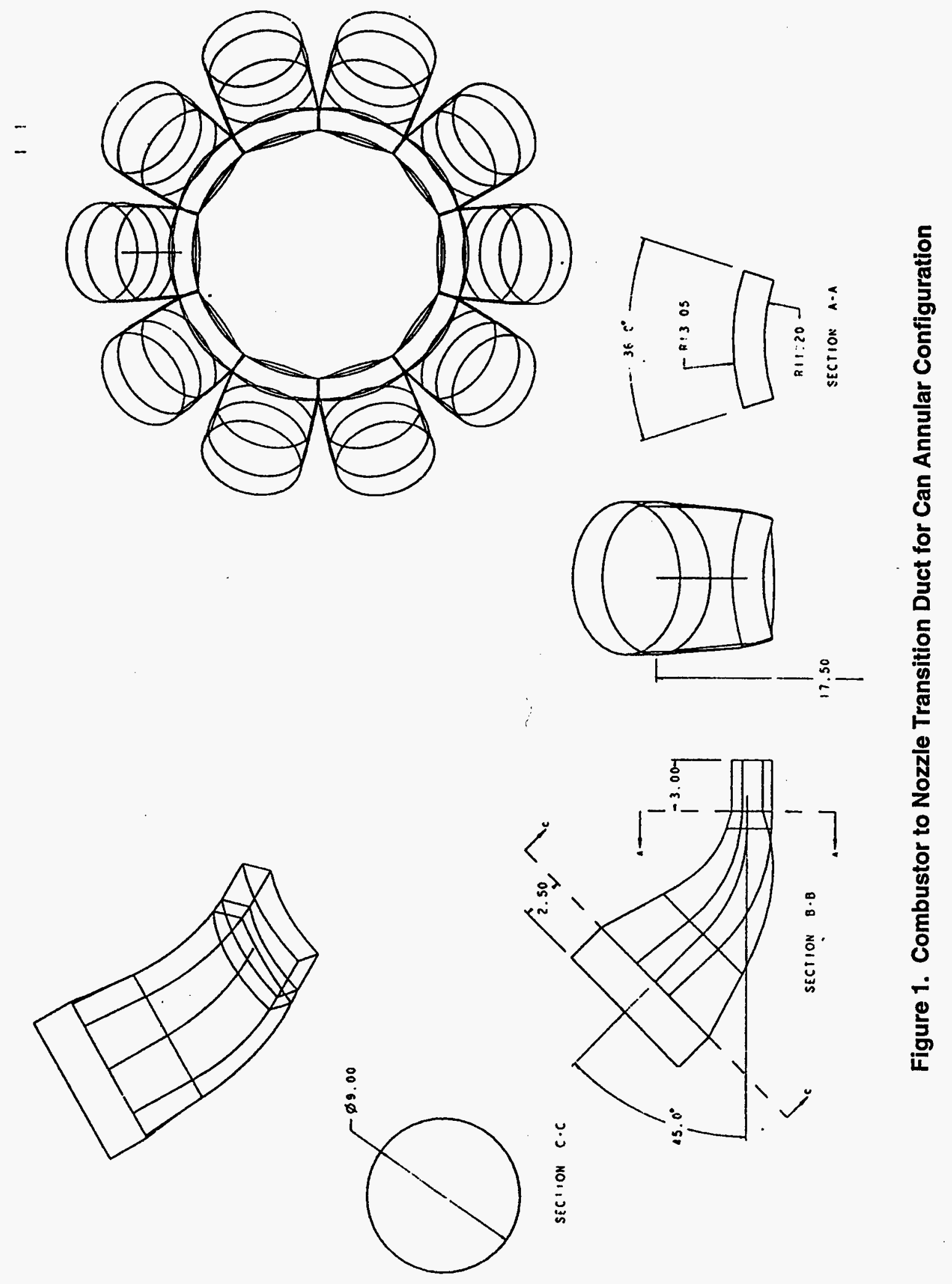




\subsection{DESIGN, ANALYSIS AND FABRICATION OF THE TRANSITION DUCT}

Work started on this component in July 1995. A PRO-E computer model of the duct was completed by Solar and was reviewed by BFG. Solar and BFG iterated on the design along with its electronic model. BFG developed a preliminary concept for attachment of the duct to the surrounding metallic structure (Figure 2). The duct is constrained at the inlet, but not at the outlet. BFG indicated that the design accounts for thermal expansion of the part.

Stress analysis was performed on the duct to determine the maximum stresses and an appropriate thickness for the part. Results of the stress analysis are shown in Figure 3. The preliminary design analysis indicated that 0.10 inch is an adequate thickness for the part.

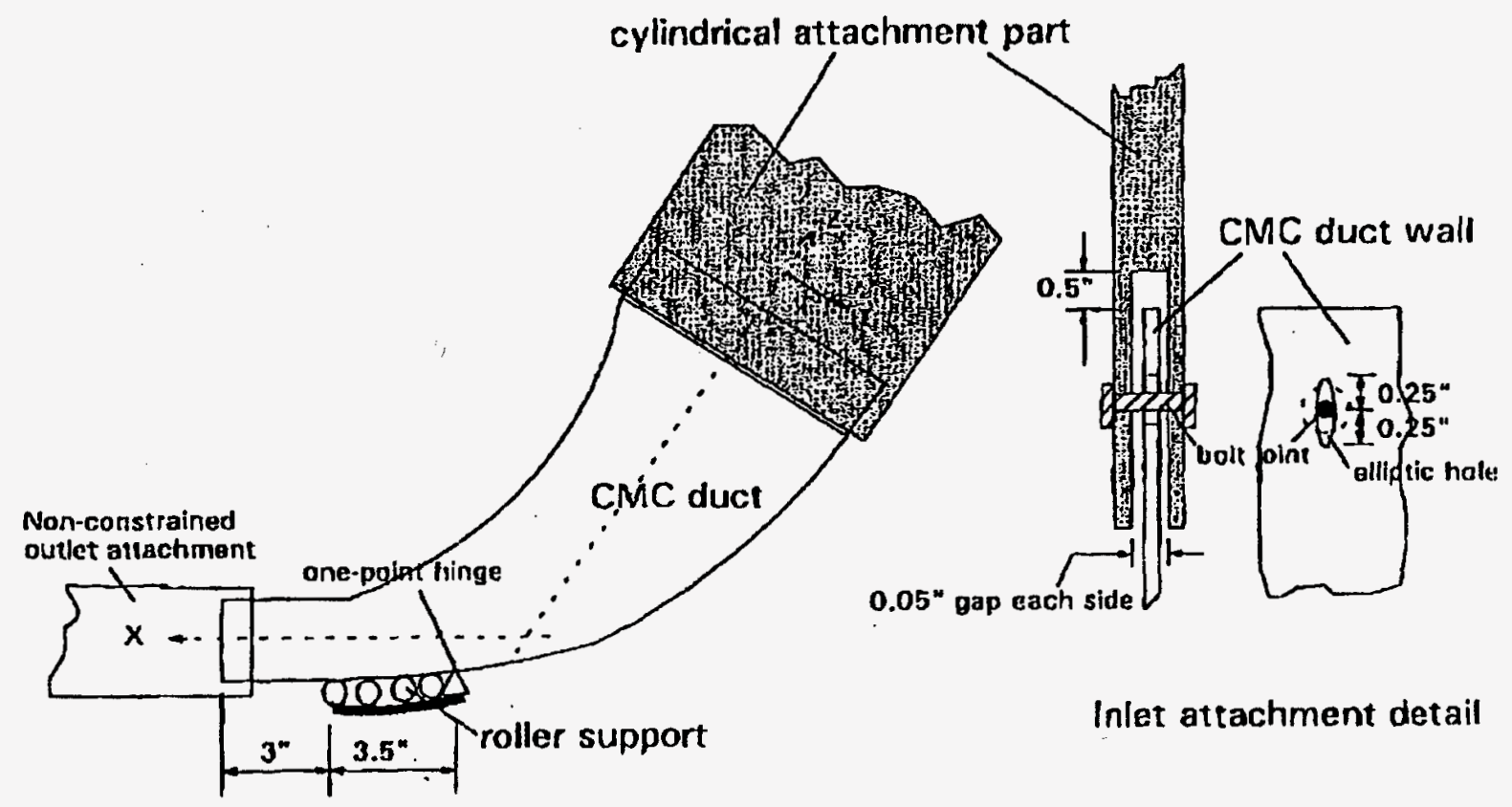

Figure 2. Preliminary Transition Duct Attachment Design 


\subsection{COORDINATION WITH ATS PHASE III PROGRAM}

Due to a change in scope and statement of work for this task, activities were not started until July 1995. Therefore, a number of items are being completed under Phase III.

The duct tooling design is complete, and fabrication of the graphite tool has begun. BFG is using an outside tooling manufacturer, MWI Electrotech in Rochester, NY, for the tooling fabrication. Machining of the tool was delayed by complications with the computer model files. BFG expects to receive the tool by $7 / 29 / 96$. The braided Nicalon preforms for the duct were completed and received by BFG. Part fabrication will begin in August. The part is scheduled for delivery to Solar in mid-October.

The braided panels for life prediction test coupons are in fabrication. Testing is scheduled to begin in early August and be completed by the beginning of September. BFG will conduct a final design analysis when the life prediction data is available. 
M98002022

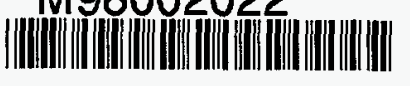

Report Number (14) DOE/nC/30246-5814

subl. Date (11) 19970630

sponsor Code (18) $\mathrm{DOE} / \mathrm{EE}, X F$

JC Category (19) $\underline{\text { UC }-101, D O E / E R}$

DOE 